\title{
Correction to: Assessing reanalysis data for understanding rainfall climatology and variability over Central Equatorial Africa
}

\author{
Wenjian Hua ${ }^{1,2} \cdot$ Liming Zhou $^{2} \cdot$ Sharon E. Nicholson ${ }^{3} \cdot$ Haishan Chen ${ }^{1} \cdot$ Minhua Qin ${ }^{1,2}$
}

Published online: 16 August 2019

(c) The Author(s) 2019

\section{Correction to: Climate Dynamics (2019) 53:651-669 https://doi.org/10.1007/s00382-018-04604-0}

The article Assessing reanalysis data for understanding rainfall climatology and variability over Central Equatorial Africa, written by Wenjian Hua, Liming Zhou, Sharon E. Nicholson, Haishan Chen, Minhua Qin was originally published electronically on the publisher's internet portal (currently SpringerLink) on 3 January 2019 without open access.

With the author(s)' decision to opt for Open Choice the copyright of the article changed on 20 August 2019 to $($ ) The Author(s) 2019 and the article is forthwith distributed under the terms of the Creative Commons Attribution 4.0 International License (http://creativecommons.org/licenses/ by/4.0/), which permits use, duplication, adaptation, distribution and reproduction in any medium or format, as long as you give appropriate credit to the original author(s) and the source, provide a link to the Creative Commons license and indicate if changes were made.

The original article was corrected.

The original article can be found online at https://doi.org/10.1007/ s00382-018-04604-0.

Liming Zhou

lzhou@albany.edu

1 Key Laboratory of Meteorological Disaster, Ministry of Education (KLME)/Joint International Research Laboratory of Climate and Environment Change (ILCEC)/ Collaborative Innovation Center on Forecast and Evaluation of Meteorological Disasters (CIC-FEMD), Nanjing University of Information Science and Technology, Nanjing 210044, China

2 Department of Atmospheric and Environmental Sciences, University at Albany, State University of New York, Albany, NY 12222, USA

3 Earth, Ocean and Atmospheric Science, Florida State University, Tallahassee, FL 32306, USA
Open Access This article is distributed under the terms of the Creative Commons Attribution 4.0 International License (http://creativeco mmons.org/licenses/by/4.0/), which permits unrestricted use, distribution, and reproduction in any medium, provided you give appropriate credit to the original author(s) and the source, provide a link to the Creative Commons license, and indicate if changes were made.

Publisher's Note Springer Nature remains neutral with regard to jurisdictional claims in published maps and institutional affiliations. 